\title{
Review of Virginia Page Fortna. 2008. Does peacekeeping work? (Princeton: Princeton University Press)
}

\author{
David E. Cunningham
}

Published online: 21 January 2009

(C) Springer Science + Business Media, LLC 2009

This is an excellent book which addresses an interesting, important, and understudied issue. Peacekeeping has been used in an increasing number of internal conflicts since the end of the Cold War, but we really know quite little about how effective a strategy of conflict management it is. General media descriptions of peacekeeping often focus on dramatic failures and listening to scholars and policymakers' general sentiments could suggest that it is an ineffective tool. While there are a large number of studies that examine specific cases of peacekeeping, and one recent systematic study of the role of the United Nations in "building peace" (Doyle and Sambanis 2006), Fortna's study is the first to systematically examine the effect of peacekeeping.

The book's title sums up Fortna's main research question, however, there are really three, related, questions. First, where do peacekeepers go? Do peacekeepers pick "easy" cases or go to the conflicts where they are most needed? Second, once they have been deployed, does peacekeeping actually prolong peace? Finally, if peacekeeping is effective, why? What does peacekeeping do that makes peace longer lasting? Fortna addresses each of these questions.

A major barrier to evaluating whether peacekeeping "works" is the selection problem - if peacekeepers select cases where they are most likely to be effective and we find some effect of peacekeeping on prolonging peace, it is difficult to determine whether peacekeeping has had an independent effect on the length of peace. To show that peacekeeping works, Fortna needs to first demonstrate that peacekeepers are not just picking easy conflicts. She does this by developing a statistical model to test how various indicators thought to make peace more or less stable affect the duration of peace. She limits her analysis to wars fought between 1945 and 1989 because peacekeeping in civil war was quite rare in this period, so she can capture the effect of these indicators in the absence of peacekeeping. Fortna then tests how these same indicators affect the likelihood of peacekeeping in conflicts after the Cold War. She

D. E. Cunningham $(\square)$

Department of Political Science, Iowa State University, 503 Ross Hall, Ames, IA 50011, USA

e-mail: dacunnin@iastate.edu 
shows that those factors that make peace the least stable- such as a greater number of combatants, rough terrain, lower levels of development and weaker governmentsalso make peacekeeping more likely. Peacekeepers appear to pick the hardest cases, suggesting that if they prolong peace then this effect is not the result of a selection process.

To test whether peacekeeping works, Fortna conducts quantitative analysis of the duration of peace after all ceasefires in civil war signed between 1989 and 1999. Peacekeeping does in fact make peace much longer lasting-peace is at least 50\% more likely to last after a ceasefire if peacekeepers are deployed than if they are not, and the effect is probably much greater than that.

Despite the title, the most important question here is not just whether peacekeeping works, as Fortna demonstrates it does, but why? In Chapter Four, Fortna develops a causal model for how the presence of peacekeepers makes peace more likely. Some of the causal logic has been spelled out elsewhere-such as in Walter's $(1997,2002)$ focus on the importance of monitoring disarmament during the post-conflict phase-however, Fortna develops a systematic argument for four ways that peacekeepers can enhance the prospects for a stable peace. Peacekeepers can (1) change the incentives for parties to abide by peace by raising the costs of returning to the battlefield and increasing the benefits of peace; (2) reduce uncertainty among the parties by monitoring compliance; (3) prevent an "accidental" return to warfare; and (4) prevent political abuse. She demonstrates that these mechanisms in fact are at work through detailed case studies of conflicts in Mozambique, Sierra Leone and Bangladesh (a case with no peacekeeping) based on extensive field interviews. Combatants do identify peacekeepers as important in the four ways that her argument describes and their presence, therefore, makes the implementation of peace agreements easier.

In addition to the considerable academic merits of this book, it has the advantage of being accessible to a wide range of audiences - undergraduates, graduate students, scholars, and policymakers. Here and in her previous book (Fortna 2004), Fortna has demonstrated a gift for conducting sophisticated quantitative analysis and presenting it in a way that is comprehensible to a wide audience. Her ability to combine statistical and qualitative data to test theoretical arguments should also be a model for those of us attempting to do mixed-method research.

As is inevitable with any study, I have a few small quibbles with the way it was conducted. The first is a methodological issue. Fortna is conducting an event history analysis of the duration of peace after a ceasefire. She cuts off her analysis of ceasefires in 1999 but examines the duration of peace until 2004. She does this in order to give all ceasefires at least 5 years in which to observe a failure. This is unnecessary. Event history analyses are set up to deal with the problem of "censoring." In fact, she has many cases where ceasefires fail in considerably less than 5 years and by eliminating cases from 1999-2004 she is unnecessarily limiting her sample. Expanding the analysis to all cases through 2004 and then treating the period after that as "censored" would give her greater analytical leverage over a wider range of cases.

The second point is a more general issue with the literature on civil war which tends to treat civil wars as exclusively two-party phenomena. Fortna does recognize that the number of factions affects the stability of peace (as demonstrated by Doyle 
and Sambanis 2006 as well). However, simply treating the number of groups as a right-hand side variable is insufficient. In my research (Cunningham 2006), I have shown that multiparty conflicts present a fundamentally different bargaining environment than two-party wars. Nilsson (2008) has demonstrated that in these conflicts individual parties often sign "partial peace" accords and exit the conflict, even as other groups continue fighting.

In Fortna's book, however, it appears that to be counted as a "ceasefire" all parties must be included. In Chad, for example, she identifies a ceasefire signed in 1994 which broke down in 1997. However, from 1997 on, the conflict in Chad has continued largely unabatated, but the government has signed a number of dyadic peace agreements with rebel groups that caused them to exit the conflict. In 1998, the government signed an agreement with the Armed Forces of the Federal Republic and in 1999 with the Movement for Democracy and Development. These agreements have been relatively stable despite the lack of peacekeeping. Although Chad certainly is not in "peace," if dyadic conflicts are resolved through an agreement that should be factored into the analysis in some way.

This is not just an issue about coding, but one that has direct policy relevance. Is peacekeeping only appropriate when all parties have signed a ceasefire? Fortna recognizes that the international community sends peacekeepers into ongoing wars - a South African force was deployed to Burundi in 2001 after a "peace agreement" that excluded the two main rebel groups, and a hybrid United Nations/African Union force is currently in Darfur despite continued conflict. She shows that conflicts with a greater number of factions lead to peacekeeping missions with more robust mandates. However, there is a fundamental difference between a multiparty conflict in which all parties have agreed to a ceasefire and one in which some are still fighting, and this difference should have an effect on peacekeeping. It would be nice if the book could address how or if peacekeeping can be effective when there are combatants who are not committed to peace.

Despite this limitation, Does Peacekeeping Work? is a very important study and a model of social science research that makes a major contribution and that should be read, and assigned, widely. Peacekeeping is an important topic with academic and policy relevance, and scholars interested in working in this area should start with Fortna's book.

\section{References}

Cunningham, D. E. (2006). Veto Players and Civil War Duration. American Journal of Political Science, 50(4), 875-92.

Doyle, M. W., \& Sambanis, N. (2006). Making War \& Building Peace. Princeton: Princeton University Press.

Fortna, V. P. (2004). Peace Time: Cease-Fire Agreements and the Durability of Peace. Princeton: Princeton University Press.

Nilsson, D. (2008). Partial Peace: Rebel Groups Inside and Outside of Civil War Settlements. Journal of Peace Research, 45(4), 479-95.

Walter, B. F. (1997). The Critical Barrier to Civil War Settlement. International Organization, 51(3), 335-64.

Walter, B. F. (2002). Committing to Peace: The Successful Settlement of Civil Wars. Princeton, NJ: Princeton University Press. 